\title{
ACP1 Gene Polymorphism Associated with Suicide Attempt Type in Bipolar Disorder Patients
}

\author{
Simone Becho Campos $\bowtie$, Paulo Marcos Brasil Rocha, Fernando Silva Neves, \\ Debora Marques Miranda, and Humberto Correa
}

National Institute of Science and Technology of Molecular Medicine, Neuroscience and Molecular Genetics Laboratories, Faculty of Medicine, Federal University of Minas Gerais, Belo Horizonte, MG, Brazil

Dear Editor,

The $A C P 1$ gene is expressed in fetal and adult brain, and belongs to a phosphotyrosine protein phosphatase family that acts regulating $\beta$-catenin levels. Increased amounts of $A C P 1$ result in decreased $\beta$-catenin in the cytoplasm, ${ }^{1}$ which is the opposite effect of the administration of lithium. For these reasons the $A C P 1$ seems a candidate gene to be associated both to bipolar disorder as well suicide behavior.

A recent Genome-Wide association study of attempt suicide in bipolar patients found a significantly association with the 2 p25 region which SNPs fall in a large linkage disequilibrium with a block containing the acid phosphatase 1 ( $A C P 1)$ gene region. Furthermore a microarray study show $A C P 1$ levels significantly increased in the brains of patients who committed suicide. $^{2}$

The aim of our study was to evaluate whether $A C P 1$ gene polymorphisms are associated to $\mathrm{BD}$ and/or suicide attempt in bipolar disorder patients in a different population sample.

We enrolled 541 individuals: 303 BD [(259 Type I), mean age \pm SD $42.97 \pm 12.95 ; 213$ were women] and 238 heath controls, [mean age \pm SD $45.68 \pm 20.00 ; 156$ women]. All enrolled individuals were auto-declared Caucasian and signed the informed consent form after a clear and detailed explanation of the procedures to be followed in the study.

We genotyped the rs4447635 and rs7419262 of the ACP1 gene using a 7500 Real-Time PCR System (Applied Biosystems, Foster City, CA, USA), in allelic discrimination mode.

Received: December 22, 2016 Accepted: March 6, 2017

Available online: October 12, 2017

$\triangle$ Correspondence: Simone Becho Campos

Faculty of Medicine, Federal University of Minas Gerais, Av. Prof. Alfredo Balena, 190-Santa Efigênia Belo Horizonte MG 30130-100, Brazil

Tel: +55-31-34099650, Fax: +55-31-34099134, E-mail: simonebecho@gmail.com

(c) This is an Open Access article distributed under the terms of the Creative Commons Attribution Non-Commercial License (http://creativecommons.org/licenses/by$\mathrm{nc} / 4.0$ ) which permits unrestricted non-commercial use, distribution, and reproduction in any medium, provided the original work is properly cited.
Association analysis was perfomed using UNPHASED software (Frank Dudbridge MRC Biostatistics Unit Cambridge, UK). All tests were two-tailed and the results were considered significant when $p \leq 0.05$. At least $10 \%$ of the samples were retyped for quality control.

From 303 bipolar patients 132 (43.6\%) had a history of at least one suicide attempt. No socio-demographic, genotypic or allelic differences were found between those subgroups. We further compared the genotypic and allelic frequencies between bipolar patients following the type of suicide attempt (violent or not). We found rs7419262 significant allelic and genotypic differences between the group of patients following the suicide attempt type, violent and nonviolent: [G 36 (65.09\%) vs. 71 (44.94) and C 37 (34.91) vs. 87 (55.06); in violent vs. non violent suicide attempts respectively; $\left.\chi^{2}=10.46, \mathrm{p}=0.003\right]$ and Genotypic: violent vs. non violent [GG 26 (49.06) vs. 18 (22.78); GC 17 (32.08) vs. 35 (44.30); CC 10 (18.87) vs. 26 (32.91) $\chi^{2}=$ $10.03 ; \mathrm{p}=0.009$ ]. All $\mathrm{p}$ values were correct by 1000 permutations.

Our study is a replication, with another approach, and in a different genetic origin of a previous study that showed association between $A C P 1$ gene and suicide. We here found rs7419262 $A C P 1$ gene polymorphism is associated with suicide attempt type (violent or not). Our results are in line with many previous studies showing that suicide attempt types may have different biological substrates and that violent suicide attempt is as phenotype more consistently close to completed suicide than non violent suicide attempt. ${ }^{3}$ Functional studies still need to establish the role of $A C P 1$ on psychiatric disorders especially on bipolar disorder with suicide attempts.

\section{REFERENCES}

1. Taddei ML, Chiarugi P, Cirri P, Buricchi F, Fiaschi T, Giannoni E, et al. Beta-catenin interacts with low-molecular-weight protein tyrosine phosphatase leading to cadherin-mediated cell-cell adhesion increase. 
Cancer Res 2002;62:6489-6499.

2. Willour VL, Seifuddin F, Mahon PB, Jancic D, Pirooznia M, Steele J, et al. A genome-wide association study of attempted suicide. Mol Psychiatry 2012;17:433-444.
3. Campi-Azevedo AC, Boson W, De Marco L, Romano-Silva MA, Correa $\mathrm{H}$. Association of the serotonin transporter promoter polymorphism with suicidal behavior. Mol Psychiatry 2003;8:899-900. 